\title{
Comparative Canopy Damage among Provenances of Baldcypress Associated with the Presence of Cercosporidium sequoiae (Ellis and Everth.) W.A. Baker and Partridge
}

\author{
Garry Vernon McDonald ${ }^{1,5}$ \\ Department of Horticulture, University of Arkansas, 316 Plant Science \\ Building, Fayetteville, AR 72701 \\ Geoffrey C. Denny ${ }^{1}$ \\ Gulf Coast Research and Education Center, University of Florida IFAS, \\ 14625 CR 672, Wimauma, FL 33598
}

Michael A. Arnold ${ }^{2}$ and Donita L. Bryan ${ }^{3}$

Department of Horticultural Sciences, Texas A\&M University, Mail Stop 2133, College Station, TX 77843-2133

\section{Larry Barnes ${ }^{4}$ \\ Department of Plant Pathology and Microbiology, Texas A\&M University, College Station, TX 77843-2132}

Additional index words. genotype, provenance, leaf blight, pond cypress, montezuma cypress

\begin{abstract}
Seeds of Taxodium distichum (L.) Rich. were collected, germinated, and grown from native stands ranging from Mexico, Texas, Louisiana, Mississippi, and Alabama. Twenty-two provenance selections were planted in Summer 2004 in College Station, TX, in 36 replicated single-plant replications per block for a total of 792 trees. Below-average midsummer temperatures and above-average number of rainfall events were conducive to the development of a leaf blight associated with the presence of Cercosporidium sequoiae (Ellis and Everh.) W.A. Baker and Partridge. A survey conducted in Oct. 2007 rated differential defoliation responses among provenances. Selections of Taxodium distichum var. mexicanum (Gordon) from Mexico and south Texas showed defoliation rates from $89 \%$ to $96 \%$, whereas $T$. distichum var. distichum from central Texas had defoliation ratings from $\mathbf{7 9 \%}$ to $99 \%$. With the exception of one family collected from the Sabinal River in Texas, the central Texas selections had similar defoliation compared with those from south Texas. Selections of T. distichum var. distichum and one selection of $T$. distichum var. imbricarium (Nutt.) Croom from southeastern regions (Alabama, Louisiana, Mississippi, and east Texas) showed greater tolerance to the presence of the leaf blight with $52 \%$ to $80 \%$ mean defoliation. A few individuals within these families exhibited little or no symptoms of the leaf blight. In general, those selections from highrainfall, high-humidity areas had less defoliation associated with the presence of the leaf blight fungus, although defoliation was variable among provenances within all geographical regions. These results suggest that tolerance to defoliation from $C$. sequoiae could be included in selection criteria when choosing possible germplasm releases from Taxodium distichum.
\end{abstract}

Baldcypress (Taxodium distichum) is a medium to large deciduous tree with demonstrated adaptability to many difficult landscape sites, including urban locations with compacted or depleted soils, and exposure to

\footnotetext{
Received for publication 8 Apr. 2008. Accepted for publication 11 June 2008.

${ }^{1}$ Assistant Professor.

${ }^{2}$ Professor

${ }^{3}$ Research/Teaching Assistant.

${ }^{4}$ Professor and Extension Specialist.

${ }^{5}$ To whom reprint requests should be addressed; e-mailgmcdonal@uark.edu
}

and the peninsula of Florida (Denny, 2007; Middleton and McKee, 2004; Turner and Watson, 1999). Ecotypes originating from these different provenances have shown varying tolerances to salt, drought, and $\mathrm{pH}$ extremes, which can be useful when selecting genotypes for planting in different geographical regions (Denny, 2007).

Cercosporidium blight caused by the pathogen Cercosporidium sequoiae (Ellis and Everh.) Baker and Partridge [syn. Asperisporium sequoiae (Ellis and Everh.) Sutton and Hodges; Cercospora sequoiae Ellis and Everh; Cercospora cryptomeriae Shirai; Cercospora thujina Plakidas] can infect a large number of conifer species used as ornamental plants, including taxodium (Leahy, 2000). Cercosporidium sequoiae is also the causative agent in currently prevalent occurrences of foliage and stem blight in Leyland cypress [X Cupressocyparis leylandii (Jackson \& Dallimore) Dallimore \& Jackson], a common landscape plant.

In the fall of 2007 at College Station, TX, the presence of $C$. sequoiae was associated with leaf blight on a number of Taxodium distichum genotypes of the three recognized botanical varieties from varying provenances. This article reports the results of a canopy damage survey of 22 provenances of taxodium ranging from central Mexico through central Texas and along the Gulf Coast in the southern United States, including the states of Texas, Louisiana, Mississippi, and Alabama.

\section{Materials and Methods}

Taxodium seedlings representing 22 different provenances ranging from central Mexico to the southeastern United States and including the states of Texas, Louisiana, Mississippi, and Alabama were planted on 23 July 2004 as part of a previous study (Denny, 2007) to evaluate taxodium genotypic adaptability to the local ecophysiological and climatic conditions of Brazos County, TX. The site is located in south central Texas with a U.S. Department of Agriculture plant hardiness zone of $8 \mathrm{~b}$ and a Koppen Climate Classification of $\mathrm{Cfa}$ or humid subtropical (Strahler and Strahler, 1984). Containerized seedlings were planted in a randomized complete block design with one single plant replicate of each of the 22 provenance selections per block with 36 blocks and a total of 792 seedlings. Seedlings were planted from 2.5-L containers on $0.914-\mathrm{m}$ centers in a row with $2.5 \mathrm{~m}$ between the rows in a Tabor fine sandy loam with $0 \%$ to $2 \%$ slopes. Plants were drip-irrigated as needed during the growing season. No fertilizers were added during the evaluation period. Plants were allowed to grow for four growing seasons. Maintenance was limited to irrigation and routine mechanical or chemical (glyphostate) weed control within the rows and mowing between the rows.

Symptoms of foliar chlorosis and necrosis were observed on individual tree canopies beginning in Aug. 2007. By Oct. 2007, foliar 
necrosis and defoliation was observed to be differentially affecting provenances with a range of damage from no symptoms to complete defoliation. Leaf tissue samples were randomly collected off 10 affected tree canopies and sent to the Texas Diagnostic Plant Disease Laboratory at Texas A\&M University for identification of potential causative plant pathogenic organisms. A survey was conducted on 24 Oct. 2007 to rate canopy defoliation of the 22 provenance selections before naturally occurring fall leaf senescence. Three individuals independently ranked percent defoliation to the nearest $10 \%$ on each tree. The experimental design of the original planting consisted of individual seedlings from 22 provenances planted as single-plant replicates in a randomized complete block design with 36 replications, a total of 36 individuals per provenance, and 792 individuals total. Rankings were assigned based on a percent defoliation from $0 \%$ to $100 \%$. Rankings were analyzed using the general linear models procedures in the SAS Statistical Program (Version 9.1; SAS Institute, Cary, NC) to determine significant differences in mean percent defoliation among provenances. Dead trees were treated as missing data points. Also, a count of the number of individual genotypes within the provenances, which exhibited mean defoliation in the following categories, $0 \% \leq x \leq$ $25 \%, 25 \%<x \leq 50 \%, 50 \%<x \leq 75 \%$, or $75 \%<x \leq 100 \%$, were determined. Chi square procedures were used to analyze these categorical data.

\section{Results and Discussion}

The summer of 2007 in College Station, $\mathrm{TX}$, was notable for cooler midsummer temperatures and above-average number of days with rain events (Table 1). May, June, and July 2007 all experienced rainfall events over half the days of the month. Although total rainfall did not vary much from the norm, it was much more uniformly distributed over a long time period with 65 daily rain events recorded as opposed to a 30 -year average of 33 rain events for the same time period (Table 1). Temperatures in May were $0.1{ }^{\circ} \mathrm{C}$ above average, which stimulated vegetative growth during the early growing season. Average monthly temperatures in June were $0.1{ }^{\circ} \mathrm{C}$ below normal with July

Table 1. Summer 2007 weather data for College Station, TX, giving number of days in the month with rain events, average number of rain events, and the departure of temperatures in ${ }^{\circ} \mathrm{C}$ from a 30 -year average ${ }^{\mathrm{z}}$.

\begin{tabular}{lccc}
\hline Month & $\begin{array}{c}\text { 2007 rain } \\
\text { events } \\
\text { (days) }\end{array}$ & $\begin{array}{c}\text { Avg. rain } \\
\text { events } \\
\text { (days) }\end{array}$ & $\begin{array}{c}\text { Temperature } \\
\text { departure } \\
\text { from avg. } \\
\left({ }^{\circ} \mathrm{C}\right)\end{array}$ \\
\hline May & 15 & 8 & $+0.1^{\circ} \mathrm{C}$ \\
June & 17 & 7 & $-0.1^{\circ} \mathrm{C}$ \\
July & 15 & 5 & $-3.0^{\circ} \mathrm{C}$ \\
August & 9 & 5 & $+0.7^{\circ} \mathrm{C}$ \\
September & 9 & 8 & $+1.0^{\circ} \mathrm{C}$ \\
\hline
\end{tabular}

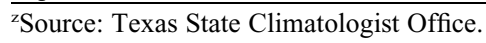

temperatures being $3.0{ }^{\circ} \mathrm{C}$ below average. These slightly lower temperatures further stimulated vegetative growth. August had $9 \mathrm{~d}$ experiencing a rain event and temperatures $0.7{ }^{\circ} \mathrm{C}$ above average with the increased temperatures occurring at night. September also had nine rain events with temperatures $1.9{ }^{\circ} \mathrm{C}$ above average with higher than normal night temperatures.

Results from the Texas Plant Disease Diagnostic Laboratory using light microscopy techniques indicated the presence of Cercosporidium sequoia, a pathogen known to infect a large number of ornamental conifer species (Leahy, 2000).

Localities for the mother trees of the 22 provenance selections included in the canopy survey are provided (Table 2). The abbreviation MX at the beginning of the provenance code indicates a Mexican source, TX a central Texas source, and EP a source from east Texas to Alabama; likewise, $M$ at the end of the code designates Taxodium distichum var. mexicanum (also known as Montezuma Cypress), D designates $T$. distichum var. distichum, and I designates $T$. distichum var. imbracarium. Selections from central Texas were from along spring-fed riparian areas growing in calcareous soils with low sodium concentrations. Eastern provenances varied from freshwater riparian streams and wetlands to areas exposed to seawater or tidal water with high concentrations of sodium chloride.

Provenances from Mexico and south Texas exhibited $89 \%$ to $96.4 \%$ mean defoliation (Table 3). These provenance locations are semiarid but with high levels of humidity. Central Texas provenance selections averaged from $98 \%$ to $99 \%$ defoliation with the exception of TX3D from the Sabinal River, which had an average defoliation rating of $79.4 \%$. TX3D showed variable defoliation associated with the presence of $C$. sequioae with one individual tree rating $0 \%$ to $25 \%$ defoliation and six individual trees in this selection averaged $50 \%$ to $75 \%$ defoliation with the remainder exhibiting in excess of $75 \%$ defoliation. Trees from central Texas are from regions with less rainfall and lower average humidity than some of those from Mexico and south Texas, which were collected closer to the Gulf of Mexico and therefore likely exposed to higher levels of relative humidity. Provenances from east Texas, Louisiana, Mississippi, and Alabama are from regions with higher amounts of rainfall and higher relative humidity than from most collection sites in Mexico and south Texas.

These data (Tables 3 and 4) suggest that baldcypress selections from eastern provenances (east Texas, Louisiana, Mississippi, and Alabama) located in higher rainfall and relative humidity level regions may be more tolerant of the presence of $C$. sequoiae $(65.8 \% \pm 1.0 \%$ mean affected canopy) than selections from provenances where it is more arid and with lower relative humidity such as from central Texas $(96.8 \% \pm 1.1 \%)$ and south Texas and Mexico $(89.9 \% \pm 1.4 \%)$. Although ratings were very consistent among the independent raters (Table 3 ), considerable variation in defoliation was present within some of the provenances (Table 4). This variable response to Cercosporidium blight infection suggests that it could be advantageous to include tolerance to the presence of $C$. sequoiae as selection criteria when evaluating Taxodium distichum germplasm for cultivar or clonal releases for use in high rainfall or high relative humidity climatic regions. Although survival over four growing seasons varied among the provenances in the study (Table 3), survival did not appear to be dependent on $C$. sequoiae resistance at this

Table 2. Geographical origins of the 22 provenances of Taxodium distichum surveyed.

\begin{tabular}{|c|c|c|c|}
\hline Provenance $^{z}$ & Latitude & Longitude & Locale \\
\hline$\overline{\mathrm{MX} 1 \mathrm{M}}$ & $25^{\circ} 52^{\prime} 48^{\prime \prime} \mathrm{N}$ & $97^{\circ} 27^{\prime} 0^{\prime \prime} \mathrm{W}$ & Southmost, TX \\
\hline MX2M & $25^{\circ} 18^{\prime} 36^{\prime \prime} \mathrm{N}$ & $104^{\circ} 38^{\prime} 24^{\prime \prime} \mathrm{W}$ & Rio Nazas, Mexico \\
\hline MX3M & $19^{\circ} 30^{\prime} 0^{\prime \prime} \mathrm{N}$ & $98^{\circ} 54^{\prime} 36^{\prime \prime} \mathrm{W}$ & Bolleros, Mexico \\
\hline MX4M & $27^{\circ} 51^{\prime} 0^{\prime \prime} \mathrm{N}$ & $101^{\circ} 7^{\prime} 48^{\prime \prime} \mathrm{W}$ & Rio Sabinas, Mexico \\
\hline MX5M & $26^{\circ} 4^{\prime} 12^{\prime \prime} \mathrm{N}$ & $97^{\circ} 54^{\prime} 36^{\prime \prime} \mathrm{W}$ & Progreso, TX \\
\hline TX1D & $29^{\circ} 55^{\prime} 12^{\prime \prime} \mathrm{N}$ & $98^{\circ} 48^{\prime} 0^{\prime \prime} \mathrm{W}$ & Guadalupe River, TX \\
\hline TX2D & $30^{\circ} 4^{\prime} 12^{\prime \prime} \mathrm{N}$ & $99^{\circ} 17^{\prime} 24^{\prime \prime} \mathrm{W}$ & Guadalupe River, TX \\
\hline TX3D & $29^{\circ} 47^{\prime} 24^{\prime \prime} \mathrm{N}$ & $99^{\circ} 35^{\prime} 24^{\prime \prime} \mathrm{W}$ & Sabinal River, TX \\
\hline TX4D & $29^{\circ} 43^{\prime} 12^{\prime \prime} \mathrm{N}$ & $99^{\circ} 45^{\prime} 0^{\prime \prime} \mathrm{W}$ & Frio River, TX \\
\hline TX5D & $29^{\circ} 9^{\prime} 36^{\prime \prime} \mathrm{N}$ & $99^{\circ} 28^{\prime} 12^{\prime \prime} \mathrm{W}$ & Sabinal River, TX \\
\hline TX6D & $29^{\circ} 0^{\prime} 36^{\prime \prime} \mathrm{N}$ & $98^{\circ} 34^{\prime} 48^{\prime \prime} \mathrm{W}$ & Atascosa River, TX \\
\hline TX7D & $29^{\circ} 46^{\prime} 12^{\prime \prime} \mathrm{N}$ & $98^{\circ} 8^{\prime} 24^{\prime \prime} \mathrm{W}$ & Guadalupe River, TX \\
\hline TX8D & $29^{\circ} 52^{\prime} 48^{\prime \prime} \mathrm{N}$ & $97^{\circ} 55^{\prime} 48^{\prime \prime} \mathrm{W}$ & $\begin{array}{l}\text { San Marcos } \\
\text { River, TX }\end{array}$ \\
\hline EP1D & $32^{\circ} 20^{\prime} 24^{\prime \prime} \mathrm{N}$ & $94^{\circ} 42^{\prime} 0^{\prime \prime} \mathrm{W}$ & Lake Cherokee, TX \\
\hline EP2D & $29^{\circ} 48^{\prime} 0^{\prime \prime} \mathrm{N}$ & $91^{\circ} 47^{\prime} 24^{\prime \prime} \mathrm{W}$ & Iberia Parish, LA \\
\hline EP3D & $29^{\circ} 5^{\prime} 24^{\prime \prime} \mathrm{N}$ & $91^{\circ} 12^{\prime} 6^{\prime \prime} \mathrm{W}$ & Bayou Teche, LA \\
\hline EP4D & $30^{\circ} 36^{\prime} 0^{\prime \prime} \mathrm{N}$ & $87^{\circ} 54^{\prime} 36^{\prime \prime} \mathrm{W}$ & Mobile Bay, AL \\
\hline EP5I & $30^{\circ} 27^{\prime} 0^{\prime \prime} \mathrm{N}$ & $88^{\circ} 6^{\prime} 36^{\prime \prime} \mathrm{W}$ & Fowl River, AL \\
\hline EP6D & $30^{\circ} 24^{\prime} 36^{\prime \prime} \mathrm{N}$ & $88^{\circ} 54^{\prime} 0^{\prime \prime} \mathrm{W}$ & Biloxi, MS \\
\hline EP7D & $30^{\circ} 23^{\prime} 24^{\prime \prime} \mathrm{N}$ & $88^{\circ} 55^{\prime} 48^{\prime \prime} \mathrm{W}$ & Biloxi, MS \\
\hline EP8D & $31^{\circ} 33^{\prime} 36^{\prime \prime} \mathrm{N}$ & $91^{\circ} 26^{\prime} 24^{\prime \prime} \mathrm{W}$ & Mississippi River, LA \\
\hline EP9D & $30^{\circ} 7^{\prime} 12^{\prime \prime} \mathrm{N}$ & $93^{\circ} 43^{\prime} 48^{\prime \prime} \mathrm{W}$ & Sabine River, TX \\
\hline
\end{tabular}

${ }^{\mathrm{z}} \mathrm{MX}$ at the beginning of the provenance code indicates a Mexican source, TX a central Texas source, and EP a source from east Texas to Alabama; $M$ at the end of the code designates Taxodium distichum var. mexicanum, D designates $T$. distichum var. distichum, and I designates T. distichum var. imbracarium. 
Table 3. Percent of the canopy exhibiting leaf blight symptoms in the form of chlorosis, necrosis, or defoliation associated with the presence of Cercosporidium sequioae in 2007 and survival over four growing seasons among provenances of Taxodium distichum on a field site in College Station, TX ${ }^{\mathrm{z}}$.

\begin{tabular}{|c|c|c|c|c|c|}
\hline Provenance & $\begin{array}{l}\text { Overall } \\
\text { mean across } \\
\text { raters }(\%)\end{array}$ & Rater $1(\%)$ & Rater $2(\%)$ & Rater $3(\%)$ & $\begin{array}{c}\text { Survival after } 4 \text { growing } \\
\text { seasons in the field } \\
\text { (no. alive of } 36 \text { ) }\end{array}$ \\
\hline$\overline{\mathrm{MX} 1 \mathrm{M}}$ & $94.6 \pm 3.0^{y}$ & $95.0 \pm 3.1^{\mathrm{x}}$ & $94.3 \pm 3.1^{\mathrm{x}}$ & $94.6 \pm 2.9^{x}$ & $28^{\mathrm{w}}$ \\
\hline MX2M & $96.4 \pm 2.7$ & $97.3 \pm 2.9$ & $95.8 \pm 2.8$ & $96.1 \pm 2.7$ & 33 \\
\hline MX3M & $94.5 \pm 3.0$ & $94.6 \pm 3.1$ & $94.6 \pm 3.1$ & $94.3 \pm 2.9$ & 28 \\
\hline MX4M & $92.1 \pm 2.7$ & $93.3 \pm 2.9$ & $91.8 \pm 2.8$ & $91.2 \pm 2.7$ & 33 \\
\hline MX5M & $89.0 \pm 2.8$ & $90.6 \pm 2.9$ & $88.1 \pm 2.9$ & $88.1 \pm 2.7$ & 32 \\
\hline TX1D & $99.4 \pm 2.8$ & $99.7 \pm 2.9$ & $99.4 \pm 2.9$ & $99.1 \pm 2.7$ & 32 \\
\hline TX2D & $98.0 \pm 2.8$ & $98.1 \pm 3.0$ & $97.7 \pm 2.9$ & $98.1 \pm 2.8$ & 31 \\
\hline TX3D & $79.4 \pm 3.1$ & $78.8 \pm 3.3$ & $79.4 \pm 3.2$ & $80.0 \pm 3.1$ & 25 \\
\hline TX4D & $98.9 \pm 2.8$ & $99.4 \pm 2.9$ & $98.6 \pm 2.9$ & $98.8 \pm 2.7$ & 32 \\
\hline TX5D & $99.8 \pm 2.9$ & $100.0 \pm 3.1$ & $99.7 \pm 2.9$ & $99.7 \pm 2.8$ & 30 \\
\hline TX6D & $96.7 \pm 2.7$ & $97.9 \pm 2.8$ & $95.7 \pm 2.8$ & $96.5 \pm 2.6$ & 34 \\
\hline TX7D & $99.8 \pm 2.9$ & $99.7 \pm 3.1$ & $99.7 \pm 3.0$ & $100.0 \pm 2.9$ & 29 \\
\hline TX8D & $99.7 \pm 2.9$ & $99.7 \pm 3.0$ & $99.8 \pm 2.9$ & $99.7 \pm 2.8$ & 30 \\
\hline EP1D & $67.5 \pm 2.9$ & $67.2 \pm 3.1$ & $67.6 \pm 3.0$ & $67.6 \pm 2.9$ & 29 \\
\hline EP2D & $62.3 \pm 2.9$ & $60.3 \pm 3.1$ & $63.4 \pm 3.0$ & $63.1 \pm 2.9$ & 29 \\
\hline EP3D & $52.8 \pm 3.1$ & $51.5 \pm 3.2$ & $53.1 \pm 3.2$ & $53.8 \pm 3.0$ & 26 \\
\hline EP4D & $69.2 \pm 2.8$ & $68.8 \pm 2.9$ & $69.1 \pm 2.9$ & $69.7 \pm 2.7$ & 32 \\
\hline EP5I & $64.2 \pm 2.7$ & $61.8 \pm 2.8$ & $64.4 \pm 2.8$ & $66.5 \pm 2.6$ & 34 \\
\hline EP6D & $80.3 \pm 2.8$ & $80.3 \pm 2.9$ & $79.5 \pm 2.9$ & $80.9 \pm 2.7$ & 32 \\
\hline EP7D & $58.2 \pm 3.2$ & $58.3 \pm 3.4$ & $55.8 \pm 3.3$ & $60.4 \pm 3.1$ & 25 \\
\hline EP8D & $63.8 \pm 2.6$ & $63.6 \pm 2.7$ & $63.3 \pm 2.7$ & $64.4 \pm 2.6$ & 36 \\
\hline EP9D & $69.8 \pm 2.8$ & $68.1 \pm 3.0$ & $71.3 \pm 2.9$ & $69.7 \pm 2.8$ & 31 \\
\hline
\end{tabular}

${ }^{\mathrm{z}}$ Mean percent of canopy exhibiting leaf blight symptoms.

${ }^{\mathrm{y}}$ Means ( \pm SES) per provenance represent an average of three observers' rating on 36 individuals (108 observations per provenance) from each provenance in replicated plantings.

${ }^{x}$ Means ( \pm SES) per family represent an average 36 individuals rated by a single rater.

${ }^{\text {w}}$ Chi-square analysis indicates significant $(P \leq 0.01)$ differences among the observed means compared with the expected means (36) in the column.

Table 4. Frequency distribution of means of percentage of the canopy exhibiting leaf blight symptoms in the form of chlorosis, necrosis, or defoliation associated with the presence of Cercosporidium sequioae among provenances of Taxodium distichum at a field site in College Station, TX ${ }^{\mathrm{z}}$.

\begin{tabular}{lcccc}
\hline & & Greater than & Greater than & Greater than \\
Provenance & $0 \%$ to $25 \%$ & $25 \%$ to $50 \%$ & $50 \%$ to $75 \%$ & $75 \%$ to $100 \%$ \\
\hline MX1M & $0^{\mathrm{y}}$ & 0 & 0 & 33 \\
MX2M & 0 & 0 & 0 & 28 \\
MX3M & 0 & 0 & 0 & 33 \\
MX4M & 0 & 0 & 0 & 31 \\
MX5M & 0 & 0 & 1 & 32 \\
TX1D & 0 & 0 & 0 & 30 \\
TX2D & 0 & 0 & 1 & 16 \\
TX3D & 1 & 6 & 32 \\
TX4D & 0 & 0 & 0 & 30 \\
TX5D & 0 & 0 & 0 & 34 \\
TX6D & 0 & 0 & 29 \\
TX7D & 0 & 0 & 30 \\
TX8D & 0 & 0 & 15 \\
EP1D & 0 & 0 & 10 & 6 \\
EP2D & 3 & 15 & 5 \\
EP3D & 1 & 11 & 14 \\
EP4D & 1 & 13 & 12 \\
EP5I & 5 & 5 & 12 & 23 \\
EP6D & 1 & 5 & 6 \\
EP7D & 1 & 4 & 11 & 12 \\
EP8D & 2 & 2 & 15 & 16 \\
EP9D & 4 & 9 & 0 &
\end{tabular}

${ }^{z}$ Number of individuals with affected canopies exhibiting mean leaf blight symptoms expressed by quartiles.

${ }^{y}$ Chi-square analysis indicates significant $(P \leq 0.01)$ differences among the observed means compared with the expected means in the columns and rows. test site, which was not surprising because the severity of the observed leaf blight was likely associated with the unusual weather conditions.

Provenances from Mexico and south Texas were previously documented to have greater tolerances to soil alkalinity, foliar exposure to salt, and greater drought tolerance than more eastern provenances with those from central Texas having intermediate tolerances (Denny, 2007). This is nearly an inverse of the pattern of damage observed in this study associated with the presence of $C$. sequioae (Table 3). However, individuals within each provenance show variation in the amount of defoliation (Table 4). Although the eastern provenances present numerous possibilities for selection of individuals with apparent tolerance to the presence of $C$. sequioae, these provenances do not possess the other desirable environmental tolerances of the more western provenances. However, the individuals in TX3D with phenotypes exhibiting lower levels of foliar damage may offer hope that genotypes from these provenances with intermediate tolerances to drought, soil alkalinity, and foliar salt exposure could also be found that have a degree of tolerance to the presence of $C$. sequioae. Clonal selections may be possible from several provenances with individual phenotypes exhibiting low levels of defoliation in our experimental plots. These could then be clonally replicated from the original ortets and the ramets tested in replicated trials to confirm their genetic tolerance to the presence of $C$. sequioae.

\section{Literature Cited}

Arnold, M.A. 2002. Landscape plants for Texas and environs. 2nd ed. Stipes Publ. L.L.C., Champaign, IL.

Cox, P.W. and P. Leslie. 1988. Texas trees: A friendly guide. Corona Publ. Co., San Antonio, TX.

Denny, G.C. 2007. Evaluation of selected provenances of Taxodium distichum for drought, alkalinity and salinity tolerance, Texas A\&M University, College Station, TX. PhD Diss.

Leahy, R.M. 2000. Cercosporidium blight of leyland cypress and related conifers. Plant Pathology Circular No. 397. Jan./Feb. 2000. Fla. Dept. Aric. \& Consumer Services, Division of Plant Industry.

Middleton, B.L. and K.L. McKee. 2004. Use of a latitudinal gradient in baldcypress (Taxodium distichum) production to examine physiological controls of biotic boundaries and potential responses to environmental change. Global Ecol. Biogeography 13:247-258.

Strahler, A.N. and A.H. Strahler. 1984. Elements of physical geography. John Wiley and Sons, Hoboken, NJ.

Turner, R.G., Jr. and E. Watson (eds.). 1999. Botanica. Barnes \& Noble, Inc., New York, NY.

Watson, F.D. 1983. A taxonomic study of pondcypress and baldcypress. p. 198. North Carolina State University, Raleigh, NC. PhD Diss. 